\title{
VARIATIONS IN STRONTIUM ISOTOPIC COMPOSITION OF PARANÁ BASIN VOLCANIC ROCKS OF BRAZIL
}

\author{
M. HALPERN*, U. G. CORDANI** and M. BERENHOLC**
}

\begin{abstract}
Total $\mathrm{Rb}$ and total $\mathrm{Sr}$ contents, as well as $\mathrm{Sr}$ isotopic ratios, were analysed on seven basaltic rocks of the Parana Basin, collected in the states of Santa Catarina and Rio Grande do Sul, Brazil.

The results indicate that the rocks are not chemically and isotopically homogeneous. The variations seem to correlate with time of extrusion, and with the composition of the basement crustal rocks.

Some relatively high $\mathrm{Sr}^{87} / \mathrm{Sr}^{86}$ ratios (more than 0.714 ) were obtained, coming from the highly differentiated rocks which occur at the uppermost part of the basaltic section in Rio Grande do Sul State. These ratios are considered to be due to large seale contamination of the magmas by crustal material enriched in radiogenic strontium.
\end{abstract}

RESUMO Análises químicas de Rb total e Sr total, e análises isotópicas de estrôncio foram obtidas em sete amostras de rochas basálticas da Bacia do Paraná, provenientes dos estados meridionais brasileiros.

Os resultados indicam que as rochas são quimicamente heterogêneas em relação a tais elementos. As variações parecem ser correlacionáveis com o tempo de extrusão dos basaltos e com a composição das rochas do embasamento (crosta do tipo continental).

Alguns resultados elevados da razão isotópica $\mathrm{Sr}^{87} / \mathrm{Sr}^{86}$ (superiores a 0,714 ) foram obtidos nas amostras de rochas altamente diferenciadas que ocorrem na parte superior do plateau basáltico, no Rio Grande do Sul. Tais relações isotópicas são consideradas devidas à contaminação em larga escala dos magmas, por material crustal enriquecido em estrôncio radiogênico.

INTRODUCTION Compston et al. (1968) published strontium isotopic ratios of Mesozoic basaltic rocks from the Paraná Basin of southern Brazil. They analyzed six plagioclase concentrates, four from dolerites of São Paulo State, one from a basaltic lava flow of western Paraná State, and one from a felsic lava flow at the eastern edge of the Paraná Basin, in Paraná State. The $\mathrm{Sr}^{87} / \mathrm{Sr}^{86}$ initial ratios for those plagioclases were all very similar with an average value of 0.7057 . Compston et al. considered the basalts as derived mainly by normal differentiation processes from magma originating in the upper mantle without large scale crustal contamination.

We have analyzed seven additional samples of these rocks to examine the strontium isotope homogenity of the Paraná Basin Mesozoic volcanism. Our specimens were obtained from the southeastern edge of the Paraná Basin and include samples of unusual chemical composition. Rocks of this type have been studied by Leinz (1949) and Schneider (1964). These rocks include dacites, leidleites, hyalodacites, dellenites, and others and usually occur as the uppermost parts of the basaltic sections in the northeastern corner of Rio Grande do Sul State.

The location of the samples used in this study is shown in Fig. 1. A short petrographic description of the analyzed specimens is given in the appendix. The total rubidium and total strontium concentrations were determined by X-ray fluorescence at the University

*Institute for Geosciences, University of Texas at Dallas, Richardson, Texas 75080

**Centro de Pesquisas Geocronológicas, Universidade de São Paulo, São Paulo, Brasil 

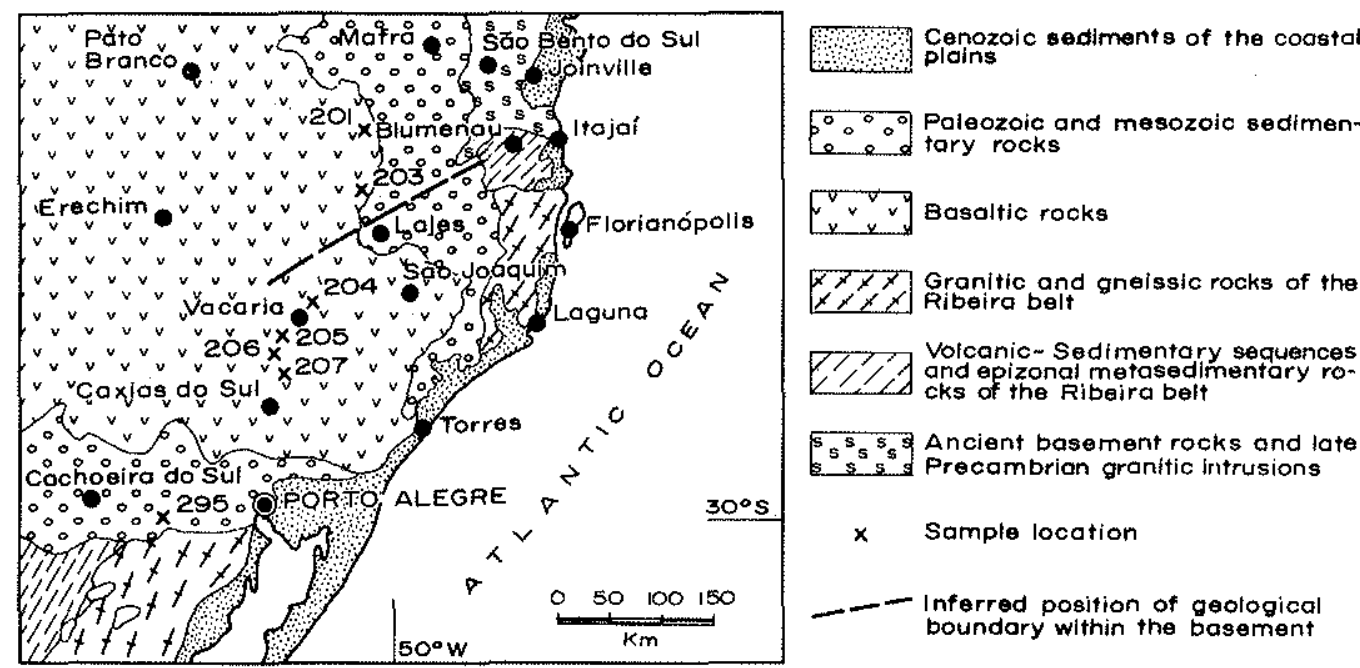

Figure I - Sample locations and simplified geological map of part of Rio Grande do Sul and Santa Catarina states of Brazil

of São Paulo using a Phillips $2 \mathrm{~kW}$ instrument. Strontium isotopic analyses (Halpern, 1968) were made on splits of the same rock powder used for the rubidium and strontium analyses.

DISCUSSION OF ANALYTICAL RESULTS Table I presents total concentrations of rubidium and strontium, $\mathrm{Rb} / \mathrm{Sr}$ ratios, and $\mathrm{Sr}^{87} / \mathrm{Sr}^{86}$ present day and initial ratios. The initial ratios were calculated assuming an average age of $120 \mathrm{~m} . \mathrm{y} .{ }^{5}$ for all of the samples and a decay constant of $1.47 \times 10^{-11} \mathrm{yr}^{-1}$. Differences of a few millions of years with respect to the age will not appreciably modify its calculated $\mathrm{Sr}^{87} / \mathrm{Sr}^{86}$ initial ratio. On the basis of rubidium and strontium chemistry, the specimens can be divided into three groups: (1) samples 201 and 203 which have high strontium concentrations of about $700 \mathrm{ppm}$, $\mathrm{Rb} / \mathrm{Sr}$ ratios of about 0.055 , and $\mathrm{Sr}^{87} / \mathrm{Sr}^{86}$ initial ratios of about 0.704 , (2) samples 205

Table I - Concentrations of rubidium and strontium, $\mathrm{Rb} / \mathrm{Sr}$ ratios, and strontium isotopic analyses of volcanic rocks from the Paraná Basin of southeastern Brazil

\begin{tabular}{lllccccc}
\hline Sample & Rock type & Location (State) & $\mathbf{R b}(\mathrm{ppm})$ & $\mathrm{Sr}(\mathrm{ppm})$ & $\mathbf{R b / S r}$ & $\begin{array}{c}\mathrm{Sr}^{87} / \mathrm{Sr}^{86} \\
\text { measured }\end{array}$ & $\begin{array}{c}\mathrm{Sr}^{87} / \mathrm{Sr}^{86} \\
\text { initial }\end{array}$ \\
\hline \hline 201 & Basalt & Santa Catarina & 39.7 & 688 & 0.058 & 0.7036 & 0.7030 \\
& & & & & & 0.7029 & \\
203 & Basalt & Santa Catarina & 37.0 & 730 & 0.051 & 0.7042 & 0.7038 \\
& & & & & & 0.7039 & \\
205 & Basalt & Rio Grande do Sul & 40.0 & 204 & 0.196 & 0.7086 & 0.7078 \\
295 & Dolerite & Rio Grande do Sul & 41.5 & 212 & 0.196 & 0.7117 & 0.7107 \\
204 & Dacite & Rio Grande do Sul & 154 & 143 & 1.08 & 0.7201 & 0.7144 \\
206 & Hyalodacite & Rio Grande do Sul & 164 & 170 & 0.964 & 0.7220 & 0.7171 \\
207 & Dacite & Rio Grande do Sul & 164 & 148 & 1.11 & 0.7239 & 0.7183 \\
\hline
\end{tabular}

Samples 204, 206, and 207 were taken from the uppermost part of the exposed volcanic section * Measured $\mathrm{Sr}^{87} / \mathrm{Sr}^{86}$ ratios were normalized to a $\mathrm{Sr}^{86} / \mathrm{Sr}^{88}$ value of 0.1194 . The normalized $\mathrm{Sr}^{87} / \mathrm{Sr}^{86}$ ratio of the M.I.T. Eimer and $\mathrm{Amend}^{\mathrm{SrCO}_{3}}$ standard was $0.7080 \pm 0.0006$ and the N.B.S. $\mathrm{SrCO}_{3}$ was $0.7100 \pm 0.0006(95 \%$ confidence level) 
and 295 which have strontium concentrations of about $200 \mathrm{ppm}, \mathrm{Rb} / \mathrm{Sr}$ ratios of about 0.2 , and $\mathrm{Sr}^{87} / \mathrm{Sr}^{86}$ ratios of the order of 0.709 , and (3) samples 204, 206 and 207 which exhibit higher rubidium concentrations by a factor of $4, \mathrm{Rb} / \mathrm{Sr}$ ratios of about 1 , and variable $\mathrm{Sr}^{87} / \mathrm{Sr}^{86}$ ratios which exceed 0.714 . The samples of this latter group have distinctive macroscopic and microscopic character and can be separated from the others of groups 1 and 2 by petrographic criteria alone (see appendix). Samples from groups 1 and 2 are indistinguishable petrographically.

An examination of radiometric ages (Amaral et al., 1966; Melfi, 1967) for some basalts of the region under study indicates that a chronologic correlation can be established between groups (1) through (3). Jurassic ages of about $145 \mathrm{~m}$.y. were obtained on two samples from Santa Catarina State and Early Cretaceous ages of about 125 to 135 m.y. for some basalts from the lower part of the volcanic succession in Rio Grande do Sul. The K-Ar dates of less than 120 m.y. characterize the more highly differentiated siliceous rocks which occur towards the top of the lava plateau. Amaral et al. (1966) considered these to represent minimum ages due to argon loss. If we omit the rocks whose ages are considered questionable, the correlation between rubidium and strontium chemistry and age suggests that the volcanic rocks of groups 1 and 2 are of different age and origin. The differences in their $\mathrm{Sr}^{87} / \mathrm{Sr}^{86}$ initial ratios may be due to regional inhomogeneity within the upper mantle, as has been suggested for the Cenozoic Snake River Plain basalts (Leeman and Manton, 1971), or due to contamination to differing degrees by crustal material. Other discrepancies, such as their $\mathrm{Rb} / \mathrm{Sr}$ ratios, and especially their total strontium concentrations are more likely explained by the first of these processes. Simple fractionation processes from a common isotopically homogeneous magma cannot explain the observed results.

An examination of the geotectonic units of the basement in southeasternmost Brazil leads us to favor a crustal contamination model. The structural trends of the basement units are northeast-southwest from Rio de Janeiro to Rio Grande do Sul (Almeida et al., 1973) and southward into eastern Uruguay (Ferrando and Fernandez, 1971). It appears reasonable to correlate the basement rocks which underlie the volcanics of groups 2 and 3 in Rio Grande do Sul with the rocks which crop out in the region between Florianópolis and Laguna and the area to the southwest of Porto Alegre (Fig. 1). These rocks consist predominantly of granitic rocks of the late Precambrian to early Palezoic Ribeira orogenic belt, many of which are highly alkaline with $\mathrm{Rb} / \mathrm{Sr}$ ratios greater than 1 and present day $\mathrm{Sr}^{87} / \mathrm{Sr}^{86}$ ratios of the order of 0.75 .

The crustal rocks which underlie the volcanics of group 1 near Lajes possibly belong to the same geotectonic province that crops out between São Bento do Sul and Blumenau (Fig. 1). This region belongs to a province of granitic to granodioritic rocks of predominantly 500 to 600 m.y. However, outcrops of granulites and basic to ultrabasic rocks are known to occur implying lower $\mathrm{Rb} / \mathrm{Sr}$ and present day $\mathrm{Sr}^{87} / \mathrm{Sr}^{86}$ ratios than the Ribeira belt. Potassium-argon dates for amphiboles from basic rocks north of Itajai (Bartorelli et al., 1968) and unpublished Rb-Sr total rock ages of granulitic rocks near São Bento do Sul give calculated ages of about 2,000 m.y. and older.

Regional differences in the geology of the basement provinces can explain the variations in the $\mathrm{Sr}^{87} / \mathrm{Sr}^{86}$ ratios of the Paraná Basin volcanic rocks we have studied. Rio Grande do Sul volcanics would have been contaminated by granitic crustal material enriched in radiogenic strontium as compared to Santa Catarina where the analyzed samples indicate a lack of sialic contamination or possibly assimilation of basic material poor in radiogenic strontium.

The highly differentiated rocks of Rio Grande do Sul suggest contamination of the parent magmas by significant amounts of crustal material with high $\mathrm{Rb} / \mathrm{Sr}$ ratios and 


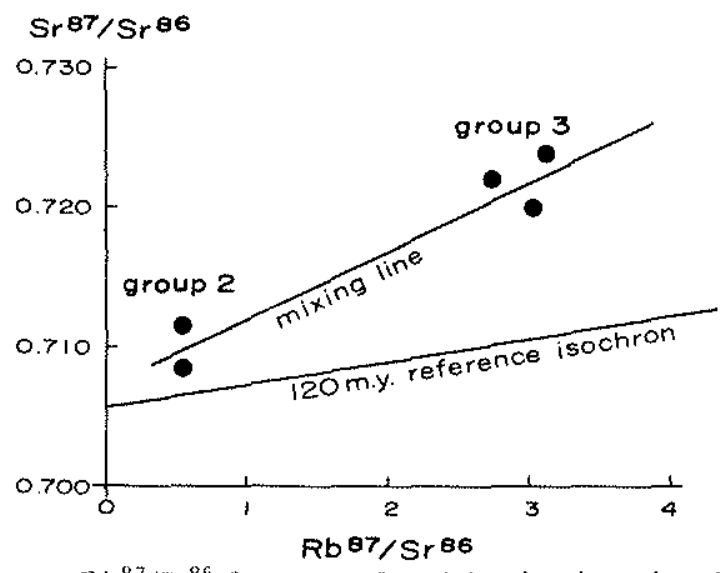

Figure $2-\mathrm{Sr}^{837} / \mathrm{Sr}^{86}$ versus $\mathrm{Rb}^{87} / \mathrm{Sr}^{86}$ for groups 2 and 3 volcanic rocks related to a hypothetical mixing line for primary magma and crustal material enriched in radiogenic strontium

radiogenic strontium. The chemical difference between these rocks and the basalts in the same region is a conspicuous increase in rubidium concentration, often by a factor of four. If the two groups are related to a common source magma, the observed $\mathrm{Sr}^{87} / \mathrm{Sr}^{86}$ ratios cannot be explained by simple fractionation processes. Figure 2 is a plot of $\mathrm{Sr}^{87} / \mathrm{Sr}^{86}$ against $\mathrm{Rb}^{87} / \mathrm{Sr}^{86}$ ratios for the samples from $\mathrm{R}$ io Grande do Sul. It illustrates a mixing line for primary magma and crustal material. For the rocks of group 3 , the contaminating material must be considered more granitic than average crustal material.

CONCLUSIONS Four main conclusions can be summarized from our analyses. (1) The Mesozoic volcanic rocks of the eastern Parana Basin are not chemically or isotopically homogeneous with respect to strontium and rubidium. (2) These variations appear to correlate with the time of extrusion of the Mesozoic lavas and with the composition of the basement crustal rocks. The possibility of regional inhomogeneities within the upper mantle cannot be excluded. (3) Some of the relatively high $\mathrm{Sr}^{87} / \mathrm{Sr}^{86}$ initial ratios of the volcanic rocks cannot be explained by normal fractionation processes and are considered due to large scale contamination by crustal material enriched in radiogenic strontium. (4) The enriched $\mathrm{Sr}^{87} / \mathrm{Sr}^{86}$ initial ratios for the uppermost parts of the lava plateau in Rio Grande do Sul State are similar to values reported for Tasmanian (Heier el al., 1965) and Antarctic. (Compston et al., 1968) dolerites of Mesozoic age.

Acknowledgements This research was in part supported by Fundação de Amparo à Pesquisa do Estado de São Paulo, Brazil, U.S. National Academỵ of Sciences Day Fund Grant Number 6, and the U.S. National Science Foundation Grant Number GV 28757 A1. We thank P. M. Hurley and W. I. Manton for commenting on the manuscript.

Appendix The following are petrographic descriptions of the samples listed in Table 1. Mineral percentages are presented only as estimates. The grain size refers to the average length of plagioclase crystals or the average diameter of the more equidimensional pyroxene or magnetite crystals. The matrix or groundmass includes plagioclase, potassium feldspar, some quartz, apatite, iron oxide, and glass. The presence of minerals such as chlorite, prenhite, or zeolite are attributed to deuteric alteration.

201: km 22l on the road between Curitiba, Parana State, and Lajes, Santa Gatarina State. Basalt: $50 \%$ plagioclase $(300 \mu), 40 \%$ pyroxenes $(200 \mu), 10 \%$ magnetite. Slightly altered poorly crystallized intersertal matrix. Intergranular texture. 
203: km 311 on the road between Curitiba, Paraná State, and Lajes, Santa Catarina State. Basalt: $65 \%$ plagioclase $(300 \mu$, crystals up to $1 \mathrm{~mm}), 25 \%$ pyroxenes $(200 \mu), 10 \%$ magnetite. Poorly crystallized intersertal matrix. Intergranular to intersertal texture.

204: km 259 on the road between Porto Alegre, Rio Grande do Sul State, and Lajes, Santa Catarina State. Dacite (or latite): $35 \%$ plagioclase $(300 \mu), 10 \%$ pyroxenes $(200 \mu)$ and $10 \%$ magnetite phenocrysts in a microcrystalline groundmass of two feldspars and quartz intergrowths. Pilotaxitic texture. 205: km 221 on the road between Porto Alegre, Rio Grande do Sul State, and Lajes, Santa Catarina State. Basalt: $60 \%$ plagioclase $(250 \mu), 30 \%$ pyroxenes $(150 \mu), 10 \%$ magnetite. Poorly crystallized intersertal matrix, with some deuteric products. Intersertal to intergranular texture.

206: km 183 on the road between Porto Alegre, Rio Grande do Sul State, and Lajes, Santa Catarina State. At the northern edge of the town of São Bernardino, Rio Grande do Sul State. Hyalodacite (or hyalolatite): $20 \%$ plagioclase $(150 \mu$ ), less than $10 \%$ pyroxenes $(80 \mu)$ and less than $5 \%$ magnetite phenocrysts, in a glassy matrix, partially devitrified. Hyalopilitic texture.

207: km 160 on the road between Porto Alegre, Rio Grande do Sul State, and Lajes, Santa Catarina State. At the southern edge of the town of São Marcos, Rio Grande do Sul State. Dacite (or latite): $30 \%$ plagioclase $(300 \mu), 5 \%$ pyroxenes $(100 \mu)$ and $5 \%$ magnetite phenocrysts in a microcrystalline groundmass of two feldspars and quartz intergrowths. Pilotaxitic texture.

295: km 149 on highway BR-290 between Porto Alegre, Rio Grande do Sul State and Cachoeira do Sul, Rio Grande do Sul State. Dolerite: $40 \%$ plagioclase ( $100 \mu$, crystals up to $500 \mu$ ), $40 \%$ pyroxenes $(60 \mu)$, less than $5 \%$ magnetite. Intersertal matrix with some devitrified glass. Intersertal to hyalophitic texture.

\section{REFERENCES}

ALMEIDA, F. F. M. de, AMARAL, G., CORDANI, U. G., and KAWASHITA, K. - 1973 The Precambrian evolution of the South American cratonic margin South of the Amazon River. Ocean Basins and Margins, vol. 1: The South Atlantic (Plenum Publ. Corp.). Ch. XI, 411-446

AMARAL, G., CORDANI, U. G., KAWASHITA, K., and REYNOLDS, J.H. - 1966 - Potassium-argon dates of basaltic rocks from Southern Brazil. Geochim. Cosmochim. Acta, 30: 159-189

BARTORELLI, A., MINIOLI, B., and KAWASHITA, K. - 1968 - Nota preliminar sobre rochas ultrabásicas de Itajubá, Santa Catarina. An. XXII Congr. Soc. Brasileira de Geologia, pp. 243-245

COMPSTON, W., McDOUGALL, I., and HEIER, K.S. - 1968 - Geochemical comparison of the mesozoic basaltic rocks of Antarctica, South Africa, South America and Tasmania. Geochim. Cosmochim. Acta, 32: 129-149

FERRANDO, L. A. y FERNANDEZ, A. N. - 1971 - Esquema tectonico y cronoestratigráfico del Predevoniano en Uruguay. Ann. XXV Cong. Soc. Brasileira de Geologia, vol. 1, pp. 199-210

HALPERN, M. - 1968 - Ages of Antarctic and Argentine rocks bearing on Continental Drift. Earth \& Planet. Sci. Letters, 5: 159-167

HEIER, K. S., COMPSTON, W., and McDOUGALL, I. - 1965 - Thorium and uranium concentrations, and the isotopic composition of strontium in the differentiated Tasmanian dolerites. Geochim. Cosmochim, Acta, 29: 643-659

LEEMAN, W.P. and MANTON, W. I. - 1971 - Strontium isotopic composition of basaltic lavas from the Snake River plain, Southern Idaho. Earth \& Planet. Sci. Letters, 11: 420-434

LEINZ, V. - 1949 - Contribuição à geologia dos derrames basálticos do Sul do Brasil. Bull. Univ. São Paulo F.F.C.L., 103, Geol. 5

MELFI, A.J. - 1967 - Potassium-argon ages for core samples of basaltic rocks from Southern Brazil. Geochim. Cosmochim. Acta, 31: 1079-1 089

SCHNEIDER, A. W. - 1964 - Contribuição à petrologia dos derrames basálticos da Bacia do Pạraná. Univ. Rio Grande do Sul Esc. Eng., 1 